Volume 11 Number 4, October-December 2017: pp. 328-341

. Copyright (C) 2017 FIAT JUSTISIA. Faculty of Law, Lampung

University, Bandarlampung, Lampung, Indonesia. ISSN:

1978-5186 | e-ISSN: 2477-6238.

Fiat Justisia is licensed under a Creative Commons Attribution 4.0 International License, which permits unrestricted use, distribution, and reproduction in any medium, provided the original work is properly cited.

\title{
The Product Characteristic of Electronic Money from the Perspective of the Negotiable Instruments Law
}

\author{
Geigiansyah Aulia Putra \\ Faculty of Law, University of Airlangga \\ geigiputra@gmail.com \\ Hilda Yunita Sabrie \\ Faculty of Law, University of Airlangga \\ hilda.sabrie@fh.unair.ac.id \\ Prawitra Thalib \\ Faculty of Law, University of Airlangga \\ prawitra@fh.unair.ac.id
}

\begin{abstract}
The development of currency trading is not only using the cash as a payment instrument for a transaction. For example is the emergence of noncash payments such as negotiable instruments. That type of instrument offers a more effective and safer way than using the cash. Along with the development of the technology, a non-cash payment innovation emerged, which characteristics, at a glance, similar to negotiable instruments, such as credit cards, debit cards, and electronic money products which gives a safer and more efficient way than using the cash for a transaction. Based on this, led to the view that non-cash payment instruments such as credit cards, debit cards, and electronic money products can be classified as negotiable instruments. However, that classification must be done by reviewing the relevant regulations, such as Commercial Code and else and also observing the doctrines in the perspective of the science concerned, to state that the development of such instruments can be classified as negotiable instruments or not.
\end{abstract}


Keywords: $\quad$ Negotiable instruments, Letter of Value, Credit Cards, Debit Cards, Electronic Money Products, Classification.

\section{A. Introduction}

The rapid development of currency trading is certainly in line with the increasing of the transaction process. The process of transactions that occur in currency trading is usually done in cash. The cash payment is the process of transactions using currency, namely paper money and coins. Along with its development, today's transaction process using currency tends to have considerable risk, ranging from the risks of theft, robbery, circulation of counterfeit money and so forth. ${ }^{1}$ It causes business people to start thinking of making a payment instrument more practical, efficient, and more secure. So based on the reason above, it appears as an instrument called negotiable instruments. These instruments arise out of the human desire to facilitate a safe, smooth and more efficient trading process. That type of instruments makes the businessmen do not have to bother to bring cash that if it can attract attention.

Furthermore, the development of the business world is also inseparable from the development of technology. The increasingly advanced technology causes Bank Indonesia as the monetary authority, banking and payment system to make it as the controller of financial stability in Indonesia. In this regard, Bank Indonesia has applied a non-cash payment instrument formulated through Bank Indonesia Regulation Number: 11/11 / PBI / 2009 as amended by Bank Indonesia Regulation Number: 14/2/2012 About the Implementation of Payment Instrument by Using Cards, from now on referred to as PBI APMK. PBI APMK provides some examples of noncash payment instruments using cards, for example, credit cards and debit cards. The development of the non-cash payment instrument has not only stopped on the credit and debit cards only, Bank Indonesia has also developed a technology in the banking sector which regulated in Bank Indonesia Regulation Number: 11/12 / PBI / 2009 About Electronic Money (Electronic Money) as amended 2 (two) times through Bank Indonesia Regulation Number: 16/8/2014 and Bank Indonesia Regulation Number: 18/17 / PBI / 2016, hereinafter referred to as PBI Electronic Money.

The existence of non-cash payment instruments such as credit cards, debit cards, and electronic money products, at a glance, have similarities with negotiable instruments, namely regarding providing efficiency, security, and speed in the transaction. Therefore, it can be argued whether the two developments of such non-cash instruments can be classified into a

\footnotetext{
${ }^{1}$ Bank Indonesia, "Upaya Meningkatkan Penggunaan Alat Pembayaran Non Tunai Melalui Pengembangan E-Money”, Working Paper, (2006), p.2
} 
negotiable instrument. The reason for the non-cash payment instrument is not previously regulated in the Commercial Code (KUHD) which is one of the securities law sources, and also whether the two instruments can be categorized as "derivatives" of negotiable instrument in accordance with the provisions in Article 1 number 10 of Law No. 10 on 1998 of Amendment to Act Number 7 of 1992 concerning on Banking. Of course, in addition to review from the side of legislation also pay attention to some doctrines of experts who develop related to it.

\section{B. Discussion}

\section{Negotiable Instruments According to Commercial Code}

The Commercial Code itself has set some specific securities instruments in its articles. Some examples of negotiable instruments outlined in the Commercial Code are among others money orders, checks, and promissory notes. To date, some examples of such negotiable instruments are often used in trading activities in the world. To the example of some negotiable instruments regulated in the Commercial Code is certainly between one instrument with another has the specificity to distinguish between one negotiable instrument with another. The first example is a money order. The arrangement of notes is regulated in Commercial Code in Book I Chapter VI Articles 100 to 177. The elucidation of those articles has not found any formal formulation of the money order, which can be found only in the general elements or terms of a negotiable instrument. Based on that, finally, there are some experts' opinions that provide understanding or definition of the notes, among others are:

1. R. Wirjono Prodjodikoro, money order means exchange. The signing of a money order tells others to pay some money to a third person. The signing is called the drawer, who is told to pay is called the drawee; the recipient of money is the one holding the note money; ${ }^{2}$

2. HMN Poerwosutjipto, a money order is a negotiable instrument containing a money order in it, dated and signed somewhere, in which the drawer gives an unconditional order to the drawee for the day of paying a sum of money to the person (recipient) appointed by the drawer or his successor in a certain place; ${ }^{3}$

3. Sharief Basir, money order, Aksep or known as a draft bank or banker's draft is a negotiable instrument containing unconditional orders from the

\footnotetext{
${ }^{2}$ R. Wirjono Prodjokoro, Hukum Wesel, Tjek, dan Aksep di Indonesia, Bandung: Sumur, (1966), p. 7.

${ }^{3}$ Sentosa Sembiring, Hukum Surat Berharga, Nuansa Aulia, (2016), p.7.
} 
issuing bank of the draft to another party (drawee) to pay a sum of money to a person or person appointed at a time has been determined; ${ }^{4}$

Based on the opinions of the experts mentioned above, it can be concluded that the money order is a negotiable instrument containing the unconditional orders from the issuer to the drawee for making the payments to the recipient or holder of the money order.

Furthermore, an example of negotiable instruments stipulated in the second Commercial Code is a check letter. The arrangement of check letters in Commercial Code is outlined in Articles 178 to 200. Similar to the money order note, the formal juridical formulations concerning check letters are not found in Commercial Code, so the formulation on checks is put forward by experts as follows: ${ }^{5}$

1. Thomas Suyanto et al., a check is an unconditional order to pay a certain amount of money to the recipient on a certain payday;

2. Achmad Anwari, citing the opinion of Lucas said, a check is a payment order to the bank of the person signing it to pay to the person who brought it or the person whose name is on the check for a sum of money contained on it;

3. Rasjim Wiraatmadja, a check is a letter in the form of an order from the customer to the bank signed by the customer concerned as the withdrawal, to unconditionally pay a certain amount of money to a particular person or party appointed by him or to the carrier;

Based on the explanations of the experts mentioned above, there is a similar thought that check is as a payment instrument that contains a payment order from the drawer or checks signer to the drawee to pay the amount of money written in the check.

The third negotiable instruments regulated in the Commercial Code that is a promissory note or often referred to as "aksep." The explanation on the definition of promissory note is also not found in the Commercial Code, but the meaning of the promissory note can be inferred from the provisions contained in Article 174 of the Commercial Code, that the promissory note is a letter containing a word capable, signed on a specific date and place, in which the signing undertakes unconditionally to pay a certain amount of money to the holder/substitute on a specific date and place. ${ }^{6}$ Various legal literature also includes some experts' opinions about the note, i.e., a statement from the signer that he or she is capable of paying a certain amount of money on a designated date to the holder or designee. ${ }^{7}$ In

\footnotetext{
${ }^{4}$ Ibid.

${ }^{5}$ Ibid., p.60

${ }^{6}$ Joni Emirzon, Hukum Surat Berharga dan Perkembangannya di Indonesia, Prenhallindo, (2002), p. 95.

${ }^{7}$ Sentosa Sembiring, Op.Cit., p.54
} 
Commercial Code, the notes are divided into 2 (two) namely the first is a promissory note of being a promes aan order, which is entitled to receive money only people/parties given the power (order) from the beginning. Second, the promissory note to the bearer (regulated in Article 229e-229k), it entitles every carrier to show the note (toonder), for the payment of money.

\section{The Context of The Negotiable Instrument in Indonesia}

Historically, the arrangements relating to negotiable Instrument in Indonesia were initially influenced by the Dutch legal system, where Indonesia was once colonized by the Dutch so that the principle of concordation of the legal system was applied. The laws prevailing in Indonesia are the same as those prevailing in the Netherlands, as well as the Dutch once colonized by France so that a bit Dutch legal system applied in Indonesia is similar to the legal system in France. The negotiable instrument arrangements applied by the Dutch at the time referred to Wetboek van Koophandel (WvK) namely the Dutch Commercial Code which adopted the Code de Commerce (Book of French Commercial Law). ${ }^{8}$

The arrangement of The negotiable instrument in Indonesia is begun and based on the Commercial Code (KUHD) adopted from the Netherlands. The arrangements are in the books I Chapter VI and Chapter VII and also spread in other laws and regulations. ${ }^{9}$ The securities regulated in the Commercial Code only relate to certain notes, such as money orders, promissory notes, checks, promissory notes and receipts for performance, and so forth. The notes as stipulated in the Commercial Code are a negotiable instrument that must have the same purpose but have the specificity that distinguishes between one negotiable instrument with others. The same purpose is to create a more secure, effective, and practical transaction climate to make the transaction process run well.

Generally, the public would elucidate the negotiable interest is a letter that has significant value by the owner, or what is contained in the interest is quite valuable to the owner, it causes the interest will have great value for the owner if a sum of money assesses it. In common with the understanding, many people assume that each letter that has a high enough value for its owner is called the negotiable interest or a letter will be considered as the negotiable interest if the letter has a high enough value when assessed with money. ${ }^{10}$ In fact, in the branch of jurisprudence, in this case, is the commercial law has divided the negotiable interest in the general view into 2 (two) parts based on the characteristics contained therein,

\footnotetext{
${ }^{8}$ Joni Emirzon, Op.Cit., p.12

${ }^{9}$ Ibid., p. 16

10 James Julianto Irawan, Surat Berharga: Suatu Tinjauan Yuridis dan Praktis, Kencana, (2014), p.4
} 
namely "a letter that has a price" or "a valuable letter" which in Dutch is called "papier van waarde" and "securities" in Dutch called "waarde papier". ${ }^{11}$

About the statement above, an interest that has a price is defined as an interest that was published only as a proof of self for the holder, namely people who are entitled to what is contained therein. More specifically, to understanding whether an interest is considered to be valuable, at least it has the following features: ${ }^{12}$

1. The letter attaches a right therein

A letter which has a price therein there is a right attached to the letter, proving that the holder has the right to what is contained in the interest;

2. It is difficult to be transferred or diverted

A letter with a price does not have an easy clause allowing the interest to be transferable or diverted, so it sometimes requires certain conditions. It is because the purpose of issuing a that has a price is not to be transferred so that if diverted will be more difficult, it does not mean it cannot be transferred;

3. Clausula Rekta

The purpose of this feature is that when the negotiable interest are given a "no substitute" clause (klausula rekta), then some scholars classify the "negotiable interest " change into a "valuable interest." It is due to the nature of the interest turning into the valuable interest, that is, regarding transferring the right is difficult.

4. Unspecified shape

A letter that has a price, in general, is not specified by law and regulation so that every publisher will be free to determine the form of the letter with the price. The freedom of determining this form makes a letter that has a price does not have the same form of the same type.

Furthermore, the definitions of the negotiable interest can be found from several experts' opinions, including: ${ }^{13}$

1. Abdulkadir Muhammad, the negotiable instrument is an instrument in which the publisher has deliberately issued as a fulfillment of achievement, in the form of payment of a sum of money;

2. Rasjum Wiraatmadja, the negotiable instrument is an interest of nature and have value as cash and can be exchanged for cash; and

3. Emmy Pangaribuan Simanjuntak, a letter is called the negotiable instrument because in the letter listed the same value with the value of

\footnotetext{
${ }^{11}$ Ibid., p.5

${ }^{12}$ Ibid., pp. 7-9

${ }^{13}$ Sentosa Sembiring, Op.Cit., pp. 11-13.
} 
the essential engagement. The basic engagement between two people is the cause of the issuance of the negotiable instrument.

Based on the experts' opinion mentioned above, it can be seen a common view in defining the negotiable instrument, which is the promise to pay in carrying out the achievements of an engagement that has occurred before known as the basic engagement or agreement background. ${ }^{14}$

The negotiable instrument has the first function as a means of payment which means as a medium of exchange or has functions such as cash. The second as a means to transfer rights which means the negotiable instrument has a role in transferring the collect rights in it. The third is as the evidence for a basic engagement, it means as a tool to prove the existence of the underlying engagement underlying the issuance of the relevant the negotiable instrument (bill of evidence) and so forth. ${ }^{15}$ Certainly, it is considered to be the negotiable instrument and fulfill those functions; the negotiable instruments must meet several requirements.

The terms for an instrument can be considered as the negotiable instrument is divided into 2 (two), namely general terms and special conditions. Common requirements include: ${ }^{16}$

a. Written form;

b. Must have a name;

c. Must be signed;

d. There is a certain amount;

e. There is an unconditional command/promise;

f. Orders or promises to pay;

g. Name of the person who has to pay;

h. There is a paid day.

The special terms in the negotiable instrument are related to things that distinguish between one negotiable instrument with others. The Commercial Code itself does not explain about the special terms on each negotiable instrument; special terms can be seen from the form of the negotiable instrument itself. One example is in negotiable instrument always accompanied by "serial number," which makes any negotiable instrument of any kind has its publishing series. So the negotiable instrument with the other one will not have the same serial number. ${ }^{17}$

An instrument is considered to be the negotiable instrument; it must have at least some functions. One of the opinions argued by Abdulkadir

\footnotetext{
${ }^{14}$ Ibid., p.13

${ }^{15}$ James Julianto Irawan, Op.Cit., p. 7

${ }^{16}$ Joni Emirzon, Op.Cit., pp. 30-36.

${ }^{17}$ Ibid.
} 
Muhammad, he said that a letter to be said as a negotiable instrument has 3 (three) functions, namely: ${ }^{18}$

1. As a means of payment (currency exchange).

The issuance of the negotiable instrument aims to fulfill the payment obligations arising from the existence of the basic engagement. For example, in the event of a sale and purchase, in which the sale and purchase event is a basic engagement, the buyer is obliged to pay the price of the goods purchased and the obligation to pay can be made using securities, such as checks or other instruments;

2. As a means of transferring the right to collect (traded easily or simply)

The issued instruments may easily change the ownership or be easily transferable, this transferable feature relates to the use or function of the instrument as a means of payment and a means of transferring the claim rights. The instrument as a means of payment and means of transferring the right to collect, then the person will not accept and use it if it is not equipped with the ease of transfer, so the securities are equipped with a clause that facilitates the holder to transfer the securities to other parties;

3. As proof of bill collateral (letter of legitimacy).

Any person holding an instrument shall be deemed to have the right to collect a payment of money to another person, in this case, the publisher or conveyor (the party ordered by the issuer to pay, for example a bank), simply by showing and delivering the instruments to the publisher or to congeal without any other necessity, in other words, this principle is as a consequence of the existence of an unconditional command element to pay some money in the negotiable instruments law. So everyone who holds it has the legitimacy to what is written in instruments.

Based on the explanation above, the negotiable instruments must function like cash, which means it can be used as a tool for transactions and can also be transferred to other parties with ease. It means the economic value is the relevant negotiable instrument. In connection in addition to that, in a negotiable instrument, there is always a clause so that the securities can be transferred. These clauses, among others, are to bearer/the carrier (aan toonder), the substitute (aan order) and on behalf (up naam).

The clause of to bearer (aan toonder) the transfer is done by hand to hand directly, as stated in the provisions of Article 613 paragraph (3) of BW namely, "the submission of debt documents of to bearer (aan toonder) is done by giving it ...". The second is the clause of the substitute (aan order)

18 Stefanus Yuwono Tedjosaputro, Penggunaan Kartu Kredit Sebagai Alat Pembayaran Dalam Transaksi Perdagangan, (Tesis: Fakultas Hukum Universitas Diponegoro), p. xx 
made by means of "endosemen," this refers to the mandate in Article 613 paragraph (4) BW, namely "... handover of each receivable because of to bearer (aan toonder) is done by submitting the letter accompanied by the endosemen ". An endorsement is an activity locating information in a negotiable instrument; it is intended that the instruments have been transferred to the next holder, as well as the holder may subsequently redirect it to another party. The third clause is on behalf (up naam), the transition way tends to be more difficult because it must be done by doing a cessie deed. It is by the provisions of Article 613 paragraph (1) of the BW, namely, "the submission of accounts receivable on behalf of and other immodest bodies, carried out by making an authentic or under-handed deed, whereby the rights to the material are delegated to other people. ${ }^{19}$

\section{The Elements of the negotiable instrument in Electronic Money Products}

The development of technology and information systems implicating the banking world is one of the triggers of the emergence of a non-cash payment instrument that recently becomes a conversation among Indonesian society. If previously the public has been familiar with non-cash payment instruments that are credit cards and debit cards, then at this time one of the non-cash payment tool products that developed in the people of Indonesia is electronic money or commonly referred to as electronic e-money money.

The rapid technological developments have caused banks to give added value to the people who use the facilities provided by banks, thus making the system shift to bank services. The Banks in conducting business activities in providing services to the community have evolved from conventional models based on paper documents to digital or electronic service models. ${ }^{20}$ This electronic money arrangement refers to the PBI on electronic money. Juridically, the definition of electronic money is contained in Article 1 number 3 of electronic money PBI which states as follows:

"Electronic money (e-money) is a means of payment that meets the following elements:

issued on the basis of the value of money deposited in advance to the issuer, the value of money deposited electronically on a media server or chip, used as a means of payment to the non-electronic issuer of the money, and the value of electronic money managed by the issuer is not a savings as referred to in the laws regulating the banking"

Based on the above explanation, electronic money is essentially cash without money (cashless money), whose value of money comes from the

\footnotetext{
${ }^{19}$ Joni Emirzon, Op.Cit., pp. 36,41,42

${ }^{20}$ Rachmadi Usman, "Karakteristik Uang Elektronik Dalam Sistem Pembayaran”, Yuridika, 32, (2017), p. 135.
} 
value of money deposited in advance to the issuer, then stored electronically in an electronic media such as server (hard drive) or card chip, which serves as a non-cash payment instrument to the non-electronic issuer concerned. The value of money in electronic money is electronic (electronic value) obtained by redeeming some cash or debiting his account in the bank and then stored electronically in electronic media in the form of storage deposit card (stored value card), the value of money is stored in the system device computer, cell phone, prepaid card or chip card. Furthermore, when the holders of electronic money use to transact then the value of money contained in electronic money will also be reduced by the value of the transaction. Otherwise, the value of electronic money will increase when receiving payment or on refilling. ${ }^{21}$

Based on the provisions in PBI electronic money, in the implementation of electronic money transactions, several parties have the functions and their respective roles. There are: ${ }^{22}$

1. The principal is a bank or institution other than a bank responsible for the management of the system and network among its members, whether acting as publisher and acquirer, in electronic money transactions in cooperation with its members based on a written agreement;

2. The Issuer is a bank or an institution other than a bank issuing electronic money;

3. The Acquirer is a bank or an institution other than a bank that cooperates with a merchant, who may process electronic money data issued by other parties;

4. The Holders are the parties who use the electronic money;

5. The Merchants are the sellers of goods and services that accept payment transactions from holders.

Based on the explanation above, at least, there is a relationship between the electronic money issuers, the holders of electronic money, and the merchants. Electronic money transactions are initiated by a legal relationship between the issuer and the holder of electronic money by depositing or exchanging a certain amount of money by the holder to the bank issuing electronic money, which is subsequently deposited electronically, which will become the value of the electronic money. The holders of electronic money in this case essentially purchase electronic money card in cash; the value of electronic money is equal to the value of money deposited to the electronic money publishers.

\footnotetext{
${ }^{21}$ Ibid., p. 140

${ }^{22}$ Peraturan Bank Indonesia Nomor 16/8/PBI/2014 Tentang Perubahan Atas Peraturan Bank Indonesia Nomor 11/12/PBI/2009 Tentang Uang Elektronik (Electronic Money).
} 
Based on the previous explanations relating to the characteristics of electronic money, when considered there is an element of negotiable instruments in it, but not as a whole. Elements of negotiable instruments that are fulfilled in electronic money is an element as a means of payment, it is equal to the element of securities contained in the debit card, while the second element can be said element is fulfilled, because in the implementation of a candidate holders of electronic money especially in the form of cards with chips that store the value of electronic money in it can easily obtain the card from the issuers of electronic money already licensed as a publisher of Bank Indonesia as mandated in Article 5 PBI electronic money, by way of buying and depositing money which will be redeemed into balances stored in electronic money electronically.

Also, electronic money can be easily transferred to others by simply handing over the electronic money, provided that electronic money is available enough balance to make transactions. Furthermore, to the third element, namely as a letter of legitimacy or charging rights, according to the authors in practice, electronic money also has in common with the debit card that has the right to collect is not the holder of electronic money, but from the evidence of the results of the transaction is usually a print outdone by the holder to the merchant and held by him which later can be used as the evidence on the management of electronic money to claim the right to claim the value of the basic engagement that has been done, so that to the third element, the authors argue that element is not fulfilled in electronic money products, it is the same as a debit card. Based on this, it can be said that electronic money also still cannot be classified as a negotiable instrument.

Furthermore, about the formal terms of electronic money itself is equated with the formal requirements of negotiable instruments, in general, are also not met. Previously, the form of electronic money itself according to Marc Hollanders are two types of electronic money products with the characteristics as follows:

Two types of products of electronic money exist:

1) Card-based products, also known as prepaid cards (and often called electronic purse or electronic wallet), are designed for making face-toface payments of small value (such as at newspaper stands, in bakeries, etc.) and for use in vending machines and parking meters. The prepaid value is typically stored in a microprocessor chip embedded in a plastic card. Electronic purses are intended such as debit card and credit cards. They are, however, in direct competition with coins and (small denomination) banknotes. Prepaid cards are intended to be used as a general, multipurpose means of payment, in contrast to the many existing single-purpose cards (such as those used for public transport) which are not considered as electronic money. 
2) Network-based or software-based products use telecommunication networks, such as the internet, to make small-value payments, usually as a substitute for credit cards. Network-based products use specialized software installed on a standard personal computer or laptop for storing the value. ${ }^{23}$

Based on that opinion, the formal form of electronic money itself can be a plastic card similar to a credit card and debit card, which has a chip technology attached to the card that is used as a place to store the value of money electronically. The second form is electronic money based on the internet network or server, which can also be used to do transactions. In relation to the formal form of electronic money products, in the previous explanation which discusses the formal form of securities which have also been regulated in the Commercial Code, when associated with the type of electronic money is formally materially also cannot be classified as a negotiable instrument, of both these instruments have in common that as a means of payment more secure than using cash. Also, in the technical setting governing electronic money is also not explained when electronic money products are categorized into one type of instruments. Based on this also, it cannot be said that this electronic money product can be classified as a negotiable instrument.

In connection with the above explanation, it is more appropriate to classify the electronic money product into a letter concept that has a valuable price or letter, as well as credit cards and debit cards. In addition, a non-cash payment instrument or instrument officially issued by Bank Indonesia as the only payment system regulator is a paper-based instrument, for example, checks, money orders, bilyet giro and others, commonly referred to as securities, then card-based instruments, such as credit cards and debit cards, and electronic-based instruments, for example, are electronic money products. ${ }^{24}$

\section{Conclusion}

The current non-cash payment instruments in Indonesia such as credit cards, debit cards, and electronic money products cannot be classified as the negotiable instruments due to several reasons, such as the non-formal requirement of not having formal form in accordance with what is regulated in Commercial Code about negotiable instruments and also in the arrangements relating to both non-cash payment instruments there is also no statement that they are said to be negotiable instruments. Then both instruments only meet some of the material requirements of the securities;

\footnotetext{
${ }^{23}$ Ibid., p. 141

${ }^{24}$ Bank Indonesia, Op.Cit., p. 8
} 
the main one is as a means of payment. Credit cards, debit cards, and electronic money products are more appropriate if they are classified into types of letters that have valuable prices or letters, as the characteristics of credit cards, debit cards and electronic money products are closer to the characteristics mentioned in the concept of valuable mail. The position of credit cards, debit cards, and electronic money products is none other than as a non-cash payment instrument that has a function as a means of payment. This is by the reference of a non-cash payment system that is based on a card (card based) and electronic based (electronic based) which has been issued by Bank Indonesia.

\section{A. Books}

\section{Bibliography}

Emirzon, Joni. (2002). Hukum Surat Berharga dan Perkembangannya di Indonesia. Prenhallindo.

Iman Prayogo dan Djoko Prakoso. (1987). Surat Berharga Alat Pembayaran dalam Masyarakat Modern. Bina Aksara

Irawan, James Julianto. (2014). Surat Berharga: Suatu Tinjauan Yuridis dan Praktis. Kencana.

Prodjokoro, R. Wirjono. (1966). Hukum Wesel, Tjek, dan Aksep di Indonesia. Bandung: Sumur

Sembiring, Sentosa. (2016). Hukum Surat Berharga. Nuansa Aulia.

Sufirman Rahman dan Eddie Rinaldy. (2013). Hukum Surat Berharga Pasar Uang. Sinar Grafika.

\section{B. Journals and Paper}

Bank Indonesia. (2006). "Upaya Meningkatkan Penggunaan Alat Pembayaran Non Tunai Melalui Pengembangan E-Money". Working Paper.

Rachmadi Usman, "Karakteristik Uang Elektronik Dalam Sistem Pembayaran”, Yuridika, (2017).

\section{Legislations}

Civil Law Book (Burgerlick Wetboek).

Republic of Indonesia Law No. 10 on 1998 concerning Amendment to Law Number 7 of 1992 concerning Banking.

The Regulation of Bank of Indonesia Number 11/11/PBI/2009 concerning the Implementation of Card-Based Payment Instrument Activities.

The Regulation of Bank of Indonesia Number 11/12/PBI/2009 concerning Electronic Money 
The Regulation of Bank of Indonesia Number 14/2/PBI/2012 concerning Amendments to Bank of Indonesia Regulation Number 11/11/PBI/2009 concerning the Implementation of Card-Based Payment Instrument Activities.

The Regulation of Bank of Indonesia Number 16/8/PBI/2014 concerning Amendments to Bank of Indonesia Regulation Number 11/12/PBI/2009 concerning Electronic Money.

The Regulation of Bank of Indonesia Number 18/17/PBI/2016 concerning Second Amendments to Bank of Indonesia Regulation Number 11/12/PBI/2009 concerning Electronic Money.

Trade Law Book (Wetboek Van Koophandel). 